\title{
Six Sigma Application: An Order Management System
}

\author{
H. N. Aleem ${ }^{1}$, S. Anwar ${ }^{4}$, I. Shariff ${ }^{3}$, Prof. Dr. Syed Abdul Aziz ${ }^{2}$ \\ ${ }^{I}$ Research Scholar, HIESS, Hamdard University, Karachi, Pakistan \\ ${ }^{2}$ Dean of HIESS, Hamdard University, Karachi, Pakistan \\ ${ }^{3}$ PIQC Institute of Quality Control, Karachi, Pakistan \\ ${ }^{4}$ Assistant Professor, Department of pharmacy, Hamdard University, Karachi, Pakistan
}

\begin{abstract}
Order processing system is investigated using Six Sigma methodology to examine application of Six Sigma Methodology to a business problem that emerges with an Information Technology (IT) Solution as an appropriate alternative. This research was carried out to exhibit Six Sigma approach to business process problem solving. Sustainability in order processing was achieved through IT solutions till any major change comes in business process logic. After conducting this research project it was proved that problem solving techniques among six sigma and traditional IT solutions are somehow similar in temperament and can be used in collaboration for getting proper elucidations. In this paper the statistical tool used is Minitab.
\end{abstract}

Keywords: Capability value (Cpk), Cause-and-Effect Diagram, Communication Plan, Control Charts, Critical to Quality Tree (CTQ), Defects per million occurrences (DPMO), DMAIC Methodology, Fish Bone Diagram, Order Management System, Pareto Charts, Process Mapping, SIPOC, Six Sigma Methodology, Systems Development Methodology

\section{INTRODUCTION}

Six Sigma Methodology provides a very stout set of tools that can be applied on a business problem to find an appropriate solution [1]. Voice of customer is the primary focus of Six Sigma by listening to the needs of process owner results in improvements to the process. Manual business processes when scrutinized through Six Sigma tools can be applied with an automated IT solution developed either in-house or commercial off the shelf solution. Basic aim of this research was to provide a sample case-based research showing how Six Sigma methodology can pilot to an IT project. Project outcomes present overview of Six Sigma process with particulars of DMAIC phases[2].

\section{OVERVIEW OF SIX Sigma}

\subsection{Six Sigma}

Six Sigma is a set of practices developed by Motorola [3] originally to improve process systematically by eliminating defects. Here, non-conformity of a product / service to its specification is termed as 'Defects'. Six Sigma focuses on:

1. Business Success can be achieved through continuous effort to reduce variation in process outputs.

2. Business processes can be Measured, Analyzed, Improved and Controlled.

3. Role of Higher management is very precarious in order to achieve best Quality Improvement results. Six Sigma is a highly capable process that can produce products within specifications. Process that produces only 3.4 Defective Products per million opportunities is said to achieve Six Sigma levels. Main methodologies of Six Sigma are:

1. DMAIC - Define, Measure, Analyze, Improve and Control

2. DMADV - Define, Measure, Analyze, Design and Verify (used while creating new processes to produce products with defect rate to minimum level)

Basis of above two methodologies is Edwards Deming's, Plan-Do-Check-Act cycle. [4]

\subsection{Six Sigma Methodology - Define, Measure, Analyze, Improve and Control (DMAIC)}

Figure 1 depicts the five process phases of DMAIC [5] as utilized in this research project. 


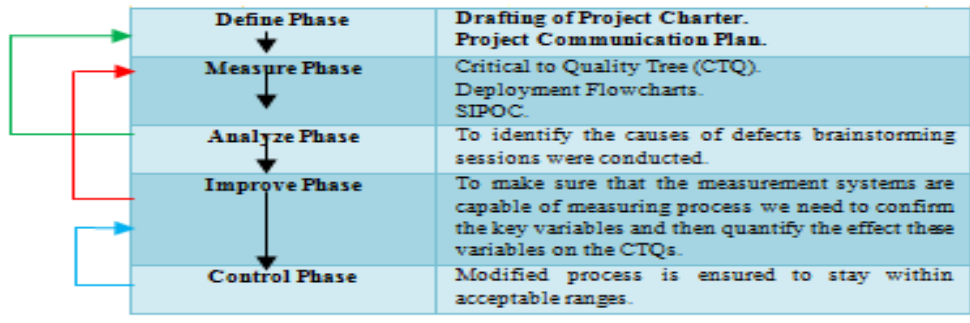

Figure 1. Five-phased DMAIC Flow Chart

\subsection{Sigma Value}

Process capability is apprehensive with measuring quality of current process compared to some target. The performance of the current process under consideration must be calculated in a Six Sigma Project in order to determine the capability of current process in meeting customer requirements. Process Capability measures are: capability value (Cpk), defects per million occurrences (DPMO) and sigma value (quality levels). Standard deviation of the data is calculates which is an input in computing long-term capability in Improve Phase. Within a span of short term six sigma recitals produces one defect per billion opportunities.

\subsection{Project Team}

Project team for Six Sigma comprised of 6 project roles assigned to 6 team members - Black belt, Green belt, Process owner (same as green belt), local champion, financial representative, and master black belt. Project team, as required, interacts with other users to execute the project and obtain desired input to the solution.

\subsection{Project Charter}

\section{DEFINE PHASE}

Figure 2 shows the summary of finalized project charter for Service Ordering Process, an outcome of several meetings with the project team. Key team members who formulated the project charter involved: Black Belt, Process Owner and local champion. For finalizing the project charter multiple meetings were held until the final version was released.

\begin{tabular}{|l|}
\multicolumn{1}{|c|}{ Project Charter } \\
\hline Project Mission: To improve Service Ordering Process. \\
\hline Opportunitr Statement: Manual registers / Paper Order sheets require a lot of handling/processing time of originating department. \\
Substantial time is required in finding/correcting error that results in a voided item (issuance of an incorrect Order). \\
\hline Proiect Boundaries/Scope: All departments who use Manual paper-based Service Ordering System. \\
\hline Objectives/Goals: Developed an improved Service Ordering System process through customized Order Management System that is \\
more proficient, lesseus voided items, and meets reporting requirements. \\
\hline Timeline: Completion of all Six Sigma Phases as per Project Schedule. \\
\hline Deliverables: Revised process to improve efficiency, soft financial savings and reduce labor effort in reporting process. Hands-on \\
training for the revised system.
\end{tabular}

Figure 2. Summary of Finalized Project Charter

\subsection{Project Communication Plan}

Communication Plan for the project is listed in Table 1.

Table 1. Communication Matrix

\begin{tabular}{|c|c|c|c|c|c|c|}
\hline $\begin{array}{c}\text { Communication } \\
\text { Type }\end{array}$ & $\begin{array}{l}\text { Objective of } \\
\text { Communication }\end{array}$ & Medium & Frequency & Audience & Owner & Deliverable \\
\hline $\begin{array}{l}\text { Project Team } \\
\text { Meetings }\end{array}$ & $\begin{array}{l}\text { Review project status } \\
\text { with team }\end{array}$ & Face to Face & Weekly & Project Team & Process Owner & $\begin{array}{l}\text { Agenda } \\
\text { NoNG }\end{array}$ \\
\hline $\begin{array}{l}\text { Preliminary Design } \\
\text { Review Meetings }\end{array}$ & $\begin{array}{c}\text { Review application's } \\
\text { design }\end{array}$ & Face to Face & As Needed & $\begin{array}{c}\text { Project Technical } \\
\text { Staff }\end{array}$ & $\begin{array}{l}\text { Technical } \\
\text { Lead }\end{array}$ & $\begin{array}{l}\text { Agenda } \\
\text { MoNG }\end{array}$ \\
\hline Techuical Meetings & $\begin{array}{l}\text { Review application's } \\
\text { technical issues }\end{array}$ & Face to Face & As Needed & $\begin{array}{c}\text { Project Technical } \\
\text { Staff }\end{array}$ & $\begin{array}{l}\text { Technical } \\
\text { Lead }\end{array}$ & $\begin{array}{l}\text { Agenda } \\
\text { NodK }\end{array}$ \\
\hline $\begin{array}{l}\text { Project Status } \\
\text { Meetings }\end{array}$ & $\begin{array}{l}\text { Discuss status of the } \\
\text { project activities }\end{array}$ & Email & Nonthly & $\begin{array}{c}\text { Sponsor } \\
\text { Project Team } \\
\text { Stakeholders }\end{array}$ & Process Owner & $\begin{array}{c}\text { Project Status } \\
\text { Report }\end{array}$ \\
\hline
\end{tabular}

\section{Measure Phase}

Several activities are associated and focused by the measure phase [6]. Flowcharting and Process mapping were used to define the current process. Defect was defined for specific improvement opportunity. Business process was reflected through a measurement system evaluation. Baseline for improvement was 
created through process capability and six sigma value calculations. Data was collected which was investigated in the analyze phase. For data collection methodology was proposed and gauged.

\subsection{High level Process Map}

High Level SIPOC Figure 3 shows an overview of the critical processes - inputs and outputs for Order processing system.

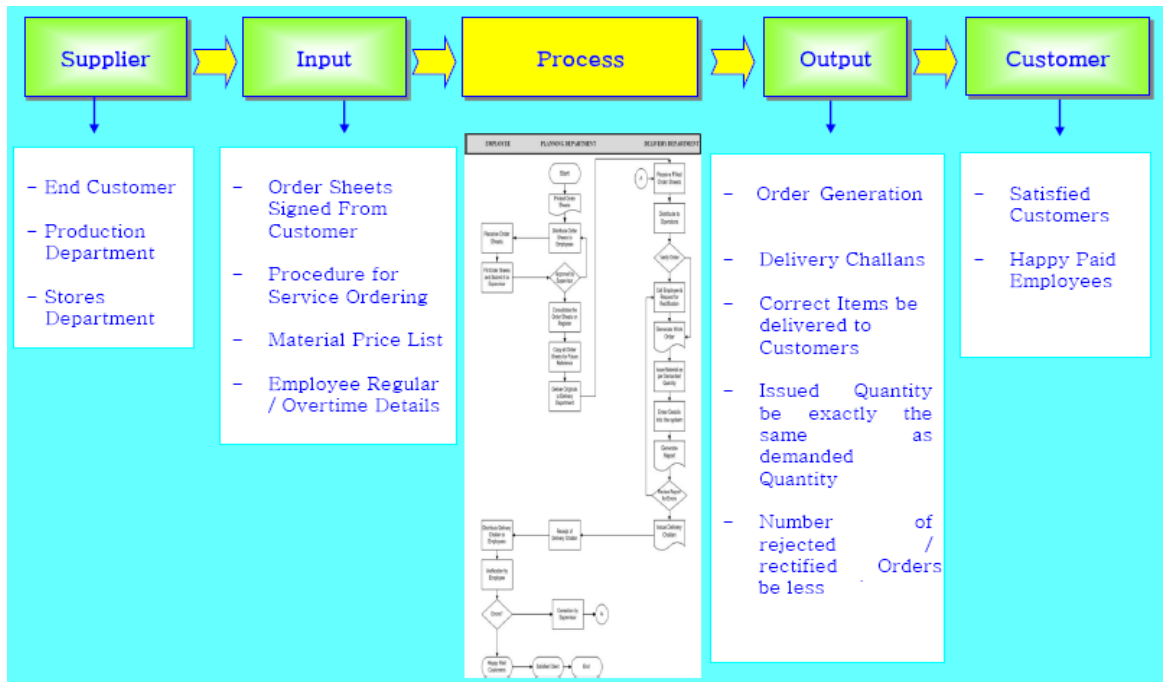

Figure 3: High level Process Map

\subsection{Deployment Flowchart}

Deployment flowcharts are an important tool within Six Sigma Methodology for understanding business processes are similar to process flowcharts developed in IT solutions for IT analysis and design [7]. To depict relationships among process activities, departments and employee a deployment flowchart Figure 4 was constructed and analyzed for detailed Order Processing System.

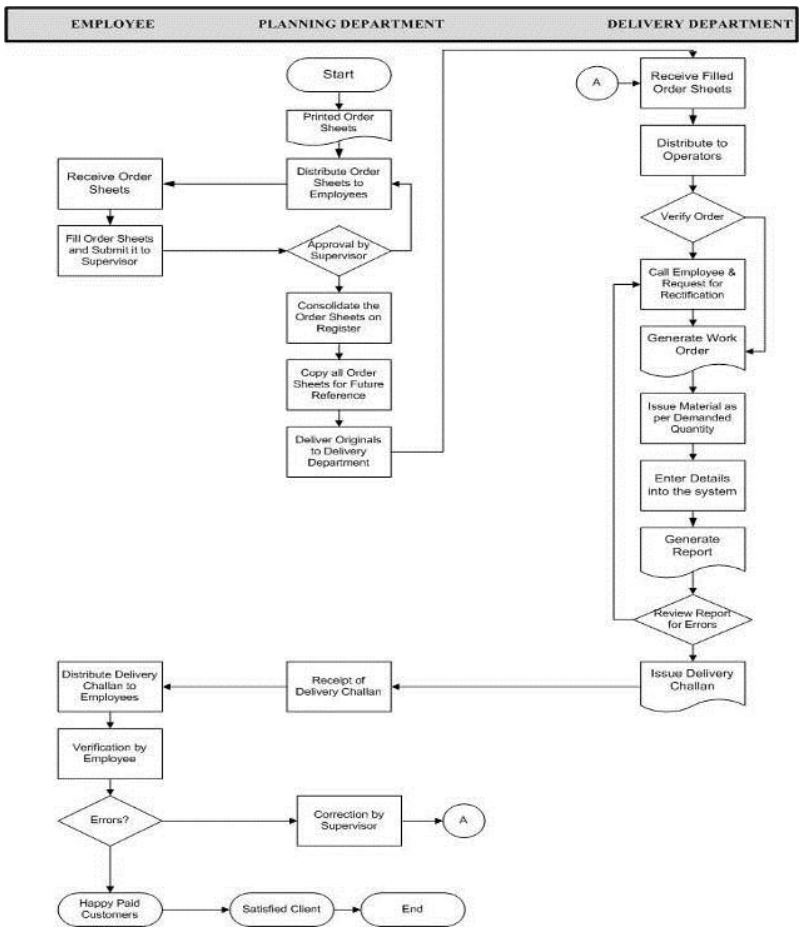

Figure 4: Service Ordering Process - Deployment Flowchart 


\subsection{Critical to Quality Tree (CTQs)}

Figure 5 illustrates the CTQs [8] for this project.

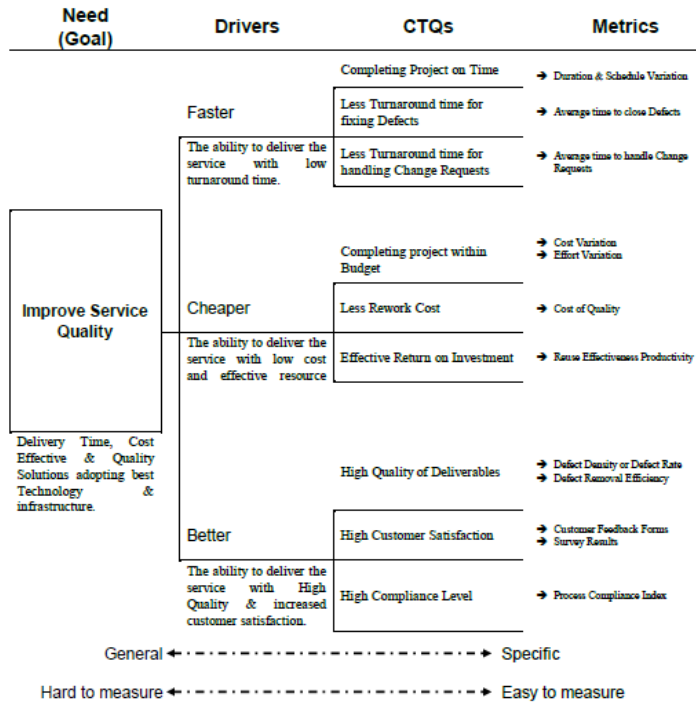

Figure 5 Critical to Quality Tree

\subsection{Measurement Plan}

Measurement Plan [9] focuses on: what needs to be measured (activities critical to the process), method for measuring and concern persons for analyzing, collecting, recording data.

\subsection{Problems / Errors in Order Processing System}

Root cause Evaluation Chart for Order Processing System is listed in Table 2.

\begin{tabular}{|c|c|c|c|c|c|}
\hline Types of Error & Root Causes & Probability & Actionable & Total & Metrics \\
\hline \multirow[t]{3}{*}{ Omitted Data } & Order Sheet was overlooked by the employee. & 3 & 3 & 6 & Missing order sheet count \\
\hline & Irresponsible behavior of supervisors. & 1 & 1 & 2 & $\begin{array}{l}\text { Missing order sheet count } \\
\text { of departments }\end{array}$ \\
\hline & $\begin{array}{l}\text { Concem person is on leave without delegation of } \\
\text { responsibility. }\end{array}$ & 1 & 1 & 2 & $\begin{array}{l}\text { Departments count of } \\
\text { unreported orders. }\end{array}$ \\
\hline Data entry issues & Human errors while key punching of data. & 1 & 9 & 10 & $\begin{array}{l}\text { Error count of Posted } \\
\text { orders. }\end{array}$ \\
\hline \multirow[t]{5}{*}{$\begin{array}{l}\text { Data Collection } \\
\text { issues }\end{array}$} & Exployees are unaware of entry process of order sheets. & 3 & 9 & 12 & $\begin{array}{l}\text { Time involved in } \\
\text { explanation of the process. }\end{array}$ \\
\hline & Unskilled/untrained employees. & 9 & 9 & 18 & On job Training count \\
\hline & Data transfer errors from manual order sheets. & 3 & 9 & 12 & $\begin{array}{l}\text { Order sheet count that } \\
\text { needs modification. }\end{array}$ \\
\hline & Material data is blank for an order. & 1 & 1 & 2 & Pending Order sheets count \\
\hline & Material cost not updated as per current pricelist. & 3 & 1 & 4 & $\begin{array}{l}\text { Cost variation of Order } \\
\text { sheets }\end{array}$ \\
\hline
\end{tabular}

\subsection{Order Processing Sigma Value Calculation}

DPMO for voided items per million employee was calculated to be 2298 which relates to sigma value of 4.45 . DPMO for Cycle time was calculated to be 289098 which relates to sigma value of 2.06 which relates to key process activity to be concentrated on through this project.

\subsection{Brainstorming Sessions}

\section{Analyze Phase}

Figure 6 shows Fish bone diagram [10] and Figure 7 Root cause Analysis chart as an outcome of brainstorming sessions which were conducted. 


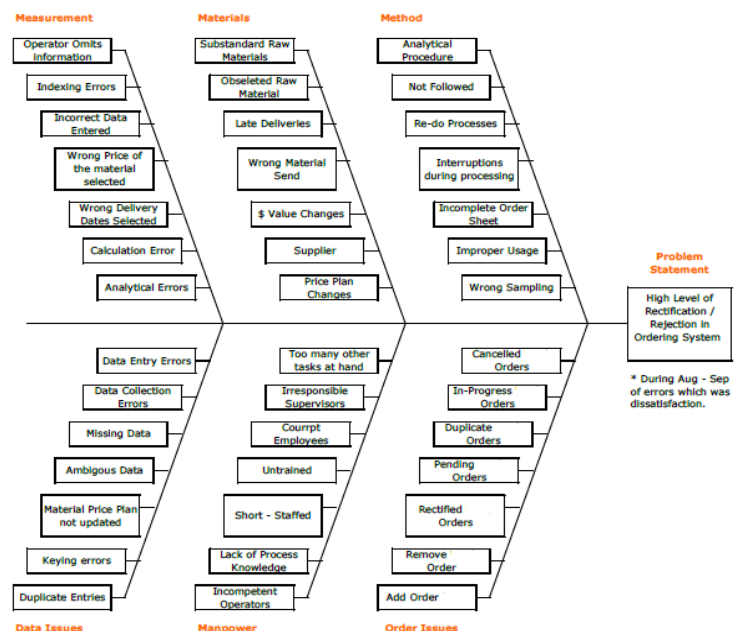

Figure 6: Fish bone diagram

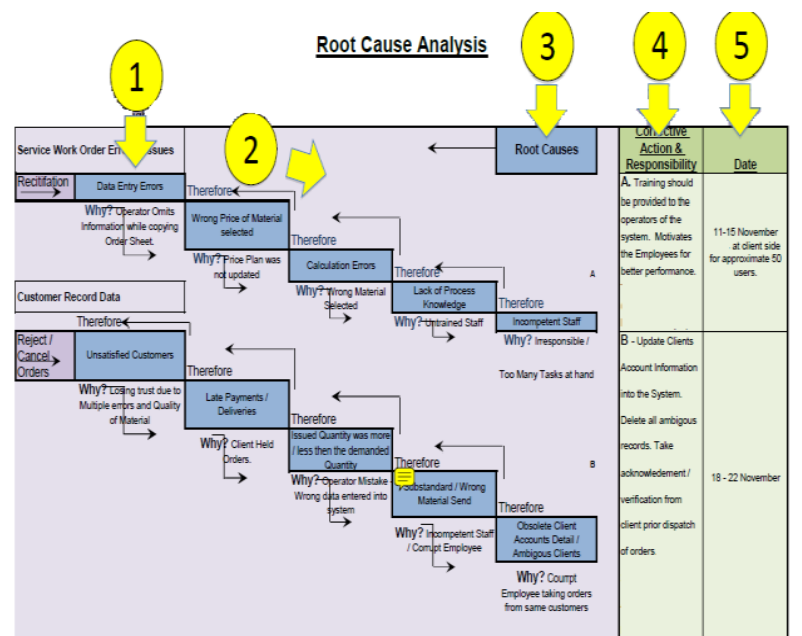

Figure 7: Root Cause Analysis Chart

\subsection{Results and Discussion}
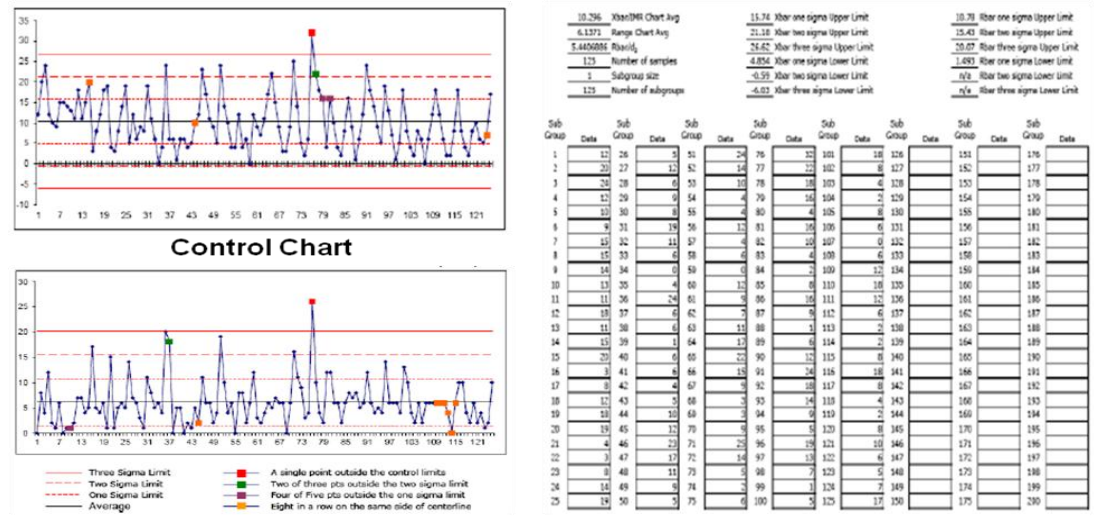

Moving Range Chart

Data

Figure 8: Order Processing Error Control Chart

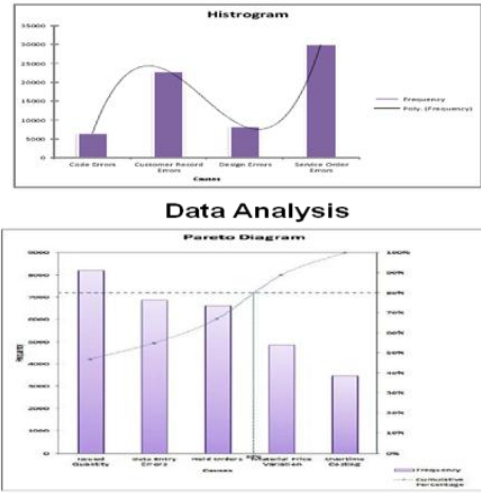

Service Order Errors

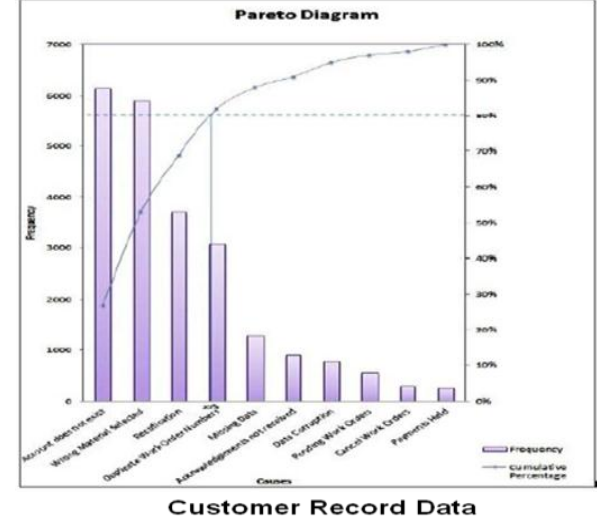

Customer Record Data

Figure 9: Pareto Analysis

\section{IMPROVE PHASE}

An Order Management System was developed in-house which catered all the problems related to order processing system and thus met the customer satisfaction. Before and after results were compared in Figure 10 thus showing that the project was on the right track with an improvement in the working and number of defects recorded when process was manual. 


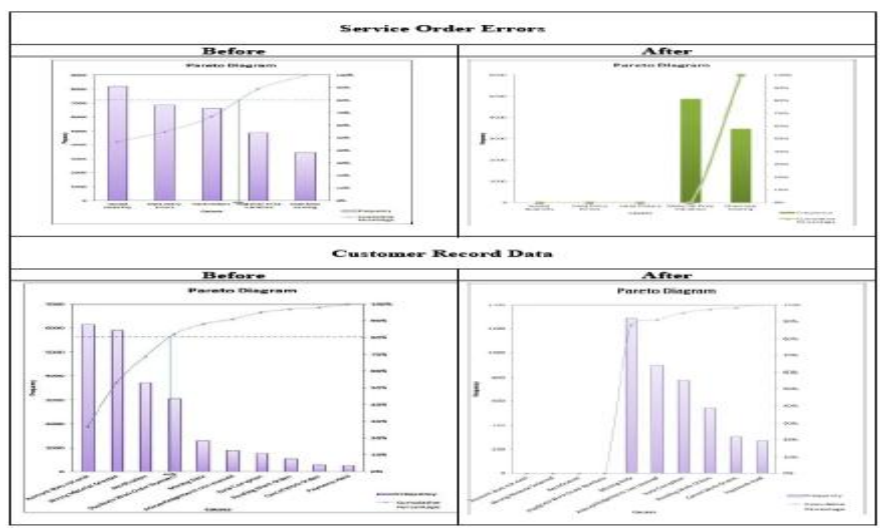

Figure 10: Improvement in system after implementation of Order Management System

VII. CONTROL Phase

Control Phase Purpose [11] is to ensure maintainability of improved process performance over a long duration with validation of results and documentation of key learning's. Table 3 lists down Control Plan Activities which were executed as planned. It was concluded that the changes and improvements were successful and sustainable as there was no major significant change in the business process and were meeting customer expectations. Day-to-day Transactional data is being entered by the data entry operators directly into the Order Management System, thus eradicating the non-value added process steps from the business process.

Table 3 Control Plan Activity Chart

\begin{tabular}{|c|l|c|c|}
\hline S/No. & \multicolumn{1}{|c|}{ Control Plan Activity } & Time Duration & Action By \\
\hline 1. & $\begin{array}{l}\text { Schedule of Solution } \\
\text { Implementation }\end{array}$ & 02 Months & $\begin{array}{c}\text { Process Owner, IT Team . Quality } \\
\text { Team, Sponsor }\end{array}$ \\
\hline 2. & Training & 03 weeks & Process Owner, Quality Team \\
\hline 3. & Cost \& Benefits Analysis & $\begin{array}{c}\text { After IT Solution was implemented and used for 03 months } \\
\text { Cost \& Benefit Analysis was carried out }\end{array}$ & Process Owner, Sponsor \\
\hline
\end{tabular}

VIII.

\section{CONCLUSION}

Order Processing System was observed through applying this methodology which resulted in Order Management System as an elucidation to the business problem. To provide IT solution to a business problem the use of Six Sigma Methodology was examined through this research. Six Sigma was driven by a project team comprising of a process owner and conducted with the assistance of a Six Sigma black belt.

Following the DMAIC approach (five-phased) of Six Sigma resulted in an IT solution which proved to be the best alternative system for extenuating the business problem as sustainability was achieved due to no major change in the business process. By eliminating manual and old ways of carrying out business processes end user got a reliable solution to its order processing system problem.

Prior to IT problem solving approaches Six Sigma methodology shares a number of problem solving tools and techniques which means that both teams can work in collaboration to share knowledge as their project methodologies are compatible to each other. Six Sigma projects that outcomes IT solutions may be studied as future research.

\section{REFERENCES}

[1] Barney, Matthew, and Tom McCarty, eds. "The New Six Sigma: A leader's guide to achieving rapid business improvement and sustainable results." Prentice Hall Professional, 2003.

[2] Douglas, P. C., Erwin, J. (2000). "Six Sigma's focus on total customer satisfaction." The Journal of Quality and Participation, 23(2), 45.

[3] Jiju Antony, Ricardo Banuelas, (2002) "Key ingredients for the effective implementation of Six Sigma program", Measuring Business Excellence, Vol. 6 Iss: 4, pp.20 - 27

[4] Schroeder, Roger G., et al. "Six Sigma: definition and underlying theory."Journal of operations Management 26.4 (2008): 536-554.

[5] Lee, S. H., and A. Haider. "Asset Lifecycle Information Quality Management: A Six-Sigma Approach." Engineering Asset Management 2011. Springer London, 2014. 461-470.

[6] Marques, Pedro A., et al. "Six Sigma Life Cycle." Technology and Manufacturing Process Selection. Springer London, 2014. 33-57.

[7] Shelly, Gary B., Thomas J. Cashman, and Harry J. Rosenblatt. "Systems analysis and design." CengageBrain. com, 2010.

[8] Gijo, E. V., and Tummala S. Rao. "Six Sigma implementation-hurdles and more hurdles." Total Quality Management \& Business Excellence 16.6 (2005): 721-725.

[9] Breyfogle III, Forrest W. "Implementing Six Sigma: smarter solutions using statistical methods.” Wiley. com, 2003.

[10] Abdollahi, Alireza. "Root Cause and Error Analysis" IRANIAN JOURNAL OF PATHOLOGY 9.2 (2014): 81-88.

[11] Snee, R.D. (2004) 'Six-Sigma: the evolution of 100 years of business improvement methodology', Int. J. Six Sigma and Competitive Advantage, Vol. 1, No. 1, pp.4-20. 